\title{
The Application and Perfection of Law MOOC
}

\author{
Jing-fang Zheng \\ Law School \\ Minjiang University \\ Fuzhou, Fujian, China
}

\begin{abstract}
Law is a practical major. Under the background of "Internet+", the application of diversified teaching modes such as MOOC poses challenges to the traditional undergraduate education of law. The proposal of MOOC teaching mode is to better promote the deepening of teaching reform. Law MOOC is a new form of MOOC course, which not only has the universal characteristics of MOOC, but also has the unique characteristics of the discipline. MOOC provides the possibility for the transformation and diversification of teaching methods of law courses to meet the needs of different students. Law MOOC has some advantages, such as learning convenience, resource sharing, reducing the cost of education and improving learning efficiency. The cultivation of law undergraduates should take the development of "Internet + " as the starting point, use MOOC and other new teaching modes to achieve mutual complementarity between law MOOC and traditional law courses, and strive to improve teaching quality, so as to train more talents for the society.
\end{abstract}

\section{Keywords-law MOOC; advantage; challenge; perfection}

\section{INTRODUCTION}

As a new type of online courses, MOOCs are popular all over the world due to their large scale and openness. At the beginning of its popularity, countries and universities pay special attention to MOOC and try to build MOOC platform.

MOOC was first created by Canadian scholar Dave Cormier and American scholar Bryan Alexander in 2008. Its full English name is Massive Open Online Courses.[1] In 2011, MOOC, as a new teaching mode, attracted wide attention worldwide. In 2012, the three major US MOOC platforms, Coursera, Udacity and Edx were established one after another. In 2013, the three platforms began large-scale overseas expansion under the dual promotion of commercial interests and educational ideals. With the continuous development of network information technology, MOOC has become increasingly influential. In 2013, colleges and universities in China started the MOOCs process. Peking University, Tsinghua University and Fudan University opened classes on Coursera platform or joined EDX and coursera respectively. Tsinghua University has also developed a sharing course platform "Xuetang online" based on Edx by taking advantage of its own technological advantages. [2]

MOOC is the biggest educational innovation since the invention of printing. More importantly, it will reform university education and reshape the territory of higher education.[3]

MOOC curriculum is different from the traditional

This paper is a phased research result of Fujian Province's Educational Reform Project "Exploration of practical curriculum system for law undergraduates under the background of law examination reform" (Project No. FBJG20190226) classroom curriculum, and its teaching method is relatively loose and flexible. MOOC is set up by professors in colleges and universities on the basis of the Internet. Its duration is mostly 6-8 weeks, and its content is usually based on prerecorded video materials, while the duration of a single video is usually 5-20 minutes or 45 minutes. Massive open online course is not only limited to video materials, but also supplemented by homework testing, learning effect evaluation, multi-dimensional interactive mode, etc. Dave Cormier described massive open online course as a course with the characteristics of common learning, openness, participation, distribution and support for lifelong online learning.[4]

The rise of MOOC is bound to have an impact on the legal teaching mode of Chinese universities. As the core content of legal education, legal teaching mode undertakes the task of imparting professional knowledge, training professional ability and training qualified talents. The quality of legal teaching mode directly affects the quality of legal education. Judging from the historical development of legal education in our country, although the legal education mode in our country has undergone several explorations and reforms, it still belongs to the "transmission-acceptance" teaching mode in general. [5] This "transmission-reception" teaching mode ignores the initiative and creativity of students and the cognitive role of students, which is not conducive to the cultivation of real legal talents with independent thinking ability and mastery of legal theory.

\section{APPLICABLE ADVANTAGES OF LAW MOOC}

The emergence of MOOCS is a revolution brought by Internet technology to education. MOOCS, a new education mode, which combines Internet and education, subverts the traditional legal education mode to some extent. Compared with traditional education, MOOC has obvious advantages in teaching concept, teaching method and teaching effect.[6]

\section{A. Convenience and Flexibility of Learning}

As a form of network course, law MOOC has the common flexibility of general network course. This flexibility is mainly reflected in two aspects: one is the flexibility of time and space, the other is the flexibility brought by the convenience of network software. Teachers and learners are not limited by fixed time and place at all, and can make learning schedule according to their own specific circumstances. The teaching video of MOOC can be watched repeatedly, and students can ponder and learn the contents they do not know much about many times. In the watching process, they can also make different adjustments to the playing progress and the playing speed according to different needs, thus improving the learning 
teaching video are replaced by new content, teachers only need to re-record a new short video, while replacing a longer teaching video requires more efforts and labor. In other words, short videos create convenient conditions for the rapid updating of teaching content.

In addition, the publicity of MOOC will inevitably face the evaluation from students and peers, which will also bring certain psychological pressure to the teachers, and then promote them to pursue higher quality of the course. All of the above factors will urge teachers to check their teaching videos, and even every material used in teaching, and examines their own teaching methods, which will naturally promote the improvement of teaching quality.

\section{Sharing High-quality Teaching Resources}

At present, the distribution of teaching resources in colleges and universities across China is uneven, and teachers in different professional fields have their own advantages in teaching. The promotion of the law MOOC has realized the sharing of high-quality teaching resources among students. Once a school teacher has made a high-quality video of the law course, other universities can introduce the course, thus improving the teaching quality as a whole and reducing unnecessary repetitive work. As an open teaching course, we can download the course materials related to MOOC on the network platform. Various communication platforms of MOOC, such as Microblog, blog, discussion post, etc., enable learners to realize the exchange of learning materials and the sharing of learning resources with the help of the platform, so as to obtain more comprehensive learning materials.

In addition, MOOC courses also contribute to the internationalization of higher education and the spread of knowledge around the world. Through the study of law MOOC, students can learn foreign law courses and absorb the essence of other countries' law education as if they were sitting in a foreign classroom. In this regard, MOOC courses also provide a shortcut for the international communication and exchange of legal culture. The sharing and convenience of high-quality teaching resources is conducive to the development of law education.

\section{CHALLENGES OF LAW MOOC}

As a type of MOOC, Law MOOC not only has the universal characteristics of massive open online course, but also has the unique characteristics of the subject, such as the subjectivity, logicality, speculative nature of the teaching contents, and strong practicality of some learning contents. This requires students to be able to apply it in combination with the practice of life cases, and the examination questions thus decided cannot all be presented with objective questions. In other words, the inherent humanistic and subjective characteristics of legal science mean that the development of legal massive open online course will face greater challenges. The main obstacle to the internationalization of China's law MOOC curriculum lies in the difficulty of learning and mastering the Chinese language. At the same time, due to the short history of development and other reasons, the maturity and advancement of the legal discipline in China lags behind that of Britain, USA, Germany and other countries.[8] legal research in our country are undergoing new changes. When the legal provisions or theoretical issues involved in a

In addition, in the MOOC learning mode, students can consolidate their knowledge on the basis of repeatedly watching various test questions, which is conducive to improving the quality of learning. The legal provisions and 
Therefore, the characteristics of law MOOC make MOOC teaching need more attention in law education.

\section{A. Not Meeting the Needs of Legal Practical Courses}

Law is a very practical subject. The teaching form in MOOC cannot meet the practical requirements of law, such as case study, legal clinic, etc. In recent years, some law colleges and universities in China are gradually introducing and learning from the teaching mode of legal clinics. This teaching mode is to introduce the clinical education mode of medical students' clinical practice into law teaching. Its outstanding feature is that under the guidance of teachers, students play the role of lawyers, use the knowledge they have learned to solve real legal practice problems, and help people who encounter legal problems in reality. The key point of clinical legal education mode is that teachers and students jointly study and analyze the case and jointly draw up a case plan. This teaching mode cannot be completed under the MOOC mode. Because the teaching in MOOC is more completed in the network environment, it is impossible to conduct case discussion and simulation under the guidance of teachers like clinic education. Other practical courses of law, such as simulation court, case discussion and so on, are also difficult to carry out effectively in MOOC mode.

\section{B. Lack of Interaction between Teachers and Students}

The lack of interaction between teachers and students makes it difficult to guarantee the quality of teaching in law MOOC. MOOC teaching mainly provides information to students through the teaching of the course. For the audience, they have few opportunities to communicate with the teachers. Although there is a fixed period of discussion class, it is extremely difficult to have meaningful and even effective dialogue in the classroom with many students. In a law MOOC class with a large number of learners, it usually takes a lot of time or is almost impossible for teachers to answer students' online questions. Therefore, most students do not have the opportunity to communicate with teachers. Because the solution of legal problems often requires close communication between teachers and students, which cannot be covered by simple formulas or short words. Moreover, various communication platforms in MOOC, such as message boards, forums, chat rooms, etc., pose severe challenges to the study of law courses. Compared with face-to-face communication, MOOC's communication may not be able to accurately express his own emotion or the expressed emotion may be misread, which will make communication lose intimacy.

\section{Not Replacing Some Functions of Traditional Campus Education}

The aim of law higher education is not only to teach but also to educate people. Even if the law MOOC can fully realize the goal of mastering the basic knowledge and skills of law, it cannot achieve the goal of educating people. As the builders of the laws, regulations and rules of the future society, law students are required to conduct themselves. The university campus is just like a small society. What you learn in it is something that massive open online course cannot bring to the learners. Classroom discussion, communication between teachers and students, and relevant legal activities after class are good opportunities for students to learn good qualities such as unity, communication and respect. More importantly, students can deeply understand what is social justice and what is legal justice, not only limited to the study of legal knowledge. In other words, MOOC teaching can't complete the emotional communication between teachers and students, the unity and cooperation between students in the traditional campus, and it is also difficult to improve students' social ability.

\section{Perfection of LAW MOOC}

\section{A. Fine Planning of MOOC Content}

For college students, they are most concerned about the quality of courses, which is also the basis of long-term learning. In a sense, the content of MOOC is more important than the form. MOOC is to compress the single content within 20 minutes, which is the condensed part of the course, so teachers should pay attention to the key points in the process of preparing lessons. In order to build a high-quality MOOC course, we must plan the course in advance; analyze the factors such as words, sounds and pictures, and divide the knowledge points scientifically and reasonably. For law teachers, the content of their lectures must be detailed and comprehensive, so as to help students master more knowledge in the shortest time. For students majoring in law, with the help of MOOC, they can interact and stimulate their enthusiasm and initiative in learning to a certain extent.[9] This kind of excellent course preparation mode and teaching mode is a challenge for teachers. In general, the production of MOOC needs to be carried out in extra-curricular time, and then it takes time to produce the corresponding MOOC. In this process, the teacher is the core producer. The teacher need to divide and sort out the previous knowledge structure of law, further establish the corresponding sub tasks, formulate the corresponding teaching design, and finally make a multimedia courseware.

\section{B. Realizing the Complementarity between MOOC and Traditional Courses}

As an online learning mode, MOOC has some difficulties in creating a learning space and environment for students to sit together. Compared with face-to-face communication learning mode, the learning effect of teachers and students across the screen is obviously not ideal. This learning mode is easy to lead to loneliness of students in learning and production, and even weaken their enthusiasm for learning. In the practice of law teaching in higher education, face-to-face communication between teachers and students has become an important content. Therefore, the teaching mode of MOOC needs to be optimized and improved. For example, in the MOOC learning stage, parts of the class hours are clearly defined as the meeting class between teachers and students. In the meeting class learning, teachers should combine the actual situation of students, give targeted answers to the questions raised by students, or let students actively participate in the face-to-face communication activities through class discussion. Compared with the pure MOOC model, this kind of meeting can't only alleviate the loneliness of students in MOOC learning, but also stimulate their enthusiasm for learning. 
aspects: content design, teaching methods and teaching forms. From the perspective of law teaching practice, MOOC can't subvert classroom teaching, but it can make up for the deficiency of classroom teaching to the greatest extent, and help to improve the quality of law education and teaching in Colleges and universities.

\section{REFERENCES}

[1] Zhu Yuan, Chen Yueqin, "Social value and development path of law mooc,” Journal of Fujian Administrative College, vol.2, pp.33-43, 2018. (In Chinese).

[2] Li Yan, "Research on Reform of Law Teaching Mode (In Chinese) Universities under the Background of MOOC," Science and Education Guide, vol.3, pp.33-34, 2016. (In Chinese).

[3] Zhang Zhiyuan, "The Influence of MOOCS development on China's higher education and its countermeasures,” Journal of Hebei Normal University, vol.2, p.116, 2014. (In Chinese).

[4] Colran S., Gilding A., "MOOCs and the Rise of Online Legal Education,” Journal of Legal Education, vol.406-413, 2014.

[5] Li Yan, "Research on Reform of Law Teaching Mode (In Chinese) Universities under the Background of MOOC," Science and Education Guide, vol.3, pp.33-34, 2016. (In Chinese).

[6] Li Yan, "Research on Reform of Law Teaching Mode (In Chinese) Universities under the Background of MOOC," Science and Education Guide, vol.3, pp.33-34, 2016. (In Chinese).

For the first time, the plan of education and training of outstanding legal talents in 2011 clearly defined the goal of law education in China as training applied and compound legal professionals. Under this goal, law education must take active measures to change the teaching mode. Under the environment of "Internet +", online courses create more learning opportunities and learning resources for college students. The emergence of MOOC just provides a reference for the reform of higher law teaching mode. This paper holds that the contemporary legal education should take MOOC as an opportunity to reform the legal teaching mode from three
[7] Michele P., "Law Schools and Technology: Where We Are and Where We Are Heading,” Journal of Legal Education, vol.64, pp.586-604, 2015.

[8] Zhu Yuan, Chen Yueqin, "Social value and development path of law MOOC,” Journal of Fujian Administrative College, vol.2, pp.33-43, 2018. (In Chinese).

[9] Li Qing, On the Construction of University MOOC and Its Application in Legal Practice Teaching, Scientific and Technological Information, vol.25, pp.118-119, 2016. (In Chinese).

[10] Wong T. M., Factors leading to effective teaching of MOOCs, Asian Association of Open Universities Journal, vol.11, pp.105-118, 2006. 